\title{
The State and Development in Africa
}

\author{
Tangie Nsoh Fonchingong*
}

\begin{abstract}
Colonisation obstructed the internal process of state formation and development in Africa and left legacies of authoritarianism, corruption and political instability. Embodied in the post-colonial state and sustained by foreign aid, these colonial legacies constitute the main obstacles to development in postcolonial Africa. The only way to liberate Africa and ensure its progress is a three-stage process involving the repudiation of foreign aid, the restructuring of territorial boundaries in accordance with African realities, and the formation of an African continental government. The African academia should be in the vanguard of African liberation by educating and mobilising the populace.
\end{abstract}

\section{Resumé}

La colonisation a constitué un frein au processus interne de formation et de développement étatique en Afrique, et nous a légué une tradition d'autoritarisme, de corruption et d'instabilité politique. Cet héritage qui est symbolisé par l'état post colonial et entretenu par l'aide extérieure, constitue un des principaux obstacles au développement de l'Afrique post coloniale. L'unique stratégie de libération de l'Afrique et de garantie de son progrès se décline en un processus en trois étapes : le rejet de l'aide extérieure, la restructuration des limites territoriales selon les réalités africaines et la formation d'un gouvernement continental africain. Le monde académique africain devrait être à l'avant-garde de la libération africaine en éduquant et mobilisant les populations.

\footnotetext{
* Political Science and Public Administration Department, the University of Buea, Cameroon.
} 


\section{Introduction}

The African continent is both the birth place of humankind and the cradle of civilisation. It is also endowed with enormous human and natural resources, with the latter 'estimated to be greater than that of almost any other continent in the world' (Nkrumah 1963: 216). Yet Africa is the least developed region in the world! And although the problem has been the subject of innumerable studies each purporting to prescribe a solution by discerning the way forward for the continent, the crisis is persisting and exacerbating, making Africa a beggarly neighbour and Africans the scum of the earth, a despicable people, so to say. Nor is there any hope for the future, as Ninsin (2000: 9) forecasts 'the prospects for Africa in the next century do not seem any better'.

But how has mother Africa, the cradle of mankind and civilisation, got into such an appalling state? In other words, what has hindered development in Africa? Modernisation literature attributes the failure of development in Africa largely to domestic or internal factors such as the domestic policy environment (The World Bank 1994; Ake 1996: 125); policy failures (Mkandawire and Soludo 1999: 23); the inability of the national bourgeoisie (Amin 1990a,1990b: 152); authoritarianism (Joseph 2003: 10); inappropriate state structures (Edigheji 2004; Lumumba-Kasongo 2002); and only marginally to external factors such as the role of the World Bank, foreign technical advisers, and foreign economic interests (Ninsin 2000).

Adopting an institutional approach in analysing the African predicament, Edigheji (2004) argues that the institutional nature and institutional perspective of the African state since independence primarily account for the continent's poor social and economic performance'. Consequently overcoming underdevelopment in Africa largely 'depends on the ability of the continent to establish state and society institutions that can successfully engineer social and economic transformation' (84). Although rightly pointing out that the 'policy informed by the Washington Consensus has entailed an usurpation of the powers and roles of African political elite over policy-making' (95), Edigheji nevertheless believes that the solution to Africa's problem is to be found in adjusting domestic power relations between the political elite who 'must rule' and the bureaucratic elite who 'must reign' and for which he proposes the 'recruitment of bureaucrats purely based on merit, predictable career paths and complemented by the need for top 
bureaucrats to share the same development agenda with the political elite' (99-100). He ignores the vital role of external factors.

Another scholar who examines the problem from an institutional perspective is Lumumba-Kasongo (2004). He also maintains that 'African people need to reinvent new state forms that can effectively address issues related to poverty and gender inequalities' (80). The reinvention of new state forms requires the reconceptualisation of the African state for which Lumumba-Kasongo proposes four options, namely: recapturing and appropriating the state by gaining access to the state's resources, managing the state's affairs according to people's objective condition; owning the state apparatuses and participating in its decision making; renaming the state by adopting a social or popular revolution of radical change of the structures of the African economies within a pan-African perspective; and through what he calls the dynamics of African traditions (103-104). In this paper, I adopt LumumbaKasongo's concept of recapturing and appropriating the state. My argument is that colonial legacies embodied in the post-colonial state and sustained by foreign aid constitute the main obstacles to development in Africa. The only way forward is to recapture and appropriate the state in a three stage process: the repudiation of foreign aid; the restructuring of territorial boundaries; and the establishment of a continental government.

The kaleidoscopic connotation of development renders it a more or less catchall concept. At times, it is used to describe the processes of social, economic and political changes at both the individual and group levels. At other times it is utilised to describe social and economic indicators such as GNP, GDP, income levels, life expectancy, etc. The same is true of 'development paradigm' which has at one time or the other been import substitution industrialisation, basic needs, structural adjustment and now, good governance. Nevertheless, as Goulet (1983: 620 ) rightly points out, 'the best model of development is one that any society forges for itself on the anvil of its specific conditions'. Whatever development entails (and it entails many things both abstract and concrete), I agree with Ake (1996: 125) that it is 'the process by which people create and recreate themselves and their life circumstances to realise higher levels of civilisation in accordance with their own choices and values. Development is something that people must do for themselves. If people are the end of development, they are also necessarily 
its agents and its means'. Therefore Africa can be developed only by Africans and not by outsiders.

This paper is divided into three parts. In the first part I seek to show that authoritarian rule or lack of democracy, corruption and political instability that are often presented as domestic constraints to development in Africa, are colonial legacies. The second part concentrates on the role of foreign aid in sustaining and reinforcing these legacies. In the third and last part I propose a three-stage way forward for Africa.

\section{Colonial Legacies}

Although colonialism used the denial of African history to establish the necessity of the 'white man's burden' and the 'mission civilatrice', much is known about political systems and governance in pre-colonial Africa. The political systems varied from highly centralised (kingdoms and empires) to highly decentralised political structures. A renowned anthropologist has written of these pre-colonial African states that in the thoroughness of their political institutions and in the skill with which social institutions were utilised to lend stability to the political structure, they exceeded anything in Europe prior to the 16th century' (Linton 1959: 120).

Pre-colonial states were not only stable, they were also governed democratically. Power within the state was decentralised which made it easier for citizens to participate fully in the political process. As a result each person was involved in political life (Busia 1962). In addition the power of centralised authority was counterbalanced by the devolution of power to regional, zonal and district chiefs. This ensured 'checks and balances and accountability’ (Osabu-Kle 2000: 79). Decision-making was based on popular consultation within the framework of a bottomup approach as opposed to the top-down authoritarian model.

The economic base of the states was autonomous and depended on the control of long-distance trade routes, and in which there were also autonomous international actors free to run their own affairs. An additional source of the state's wealth was the payment of tributes (Ibn Khaldun quoted in Muiu 2002: 25). Concerning the people and society in precolonial Africa the great Islam scholar Ibn Battuta asserted that they:

Are seldom unjust, and have a greater abhorrence of injustice than any other people... There is complete security in their country, neither traveller nor inhabitants in it has anything to fear from robbers or men of violence. They do not confiscate the property of any white man who 
dies in their country, even if it be uncounted wealth. On the contrary, they give it into the charge of some trustworthy person among the whites until the rightful heir takes possession of it (quoted in Nkrumah 1963: $3)$.

Pre-colonial Africa was thus characterised by autonomous, stable and democratically governed political systems devoid of dishonesty or corruption. But these institutions and values were destroyed by colonialism, which replaced them with authoritarianism, corruption, and political instability.

\section{The Colonial State and Authoritarianism}

State formation in pre-colonial Africa, as elsewhere, was an internal evolutionary and revolutionary process involving conquest and assimilation of groups by stronger groups. The attributes of a state, namely, an autonomous government, a national foundation based on a population of citizens and a definite territory, were the end result of this process. Unlike the pre-colonial state the colonial state in Africa did not emerge from an internal evolutionary and revolutionary process. It was externally and forcefully imposed as an instrument of suppression, not of governance, and as such, it lacked the attributes of a state. It had no autonomous government, the territorial boundaries were arbitrary and therefore uncertain while the people within the territory were regarded as subjects, not citizens, and so it also lacked a national foundation. In other words, altough the colonial state lacked legitimacy yet it had to perform its functions of suppressing a restive population of subjects and destroying their institutions and values and replacing them with those reflecting the colonisers' needs and interests.

To perform these functions the colonial state used all the political, economic, cultural, military and psychological instruments of oppression 'to weaken, kill his sense of self-worth, and zombianize the African into the living dead' (Fanon 1968: 10), thereby vindicating Alexis de Tocquevilles's 1835 observation that if we reason from what passes in the world we should almost say that the European is to the other races of mankind what man is to the lower animals, he makes them subservient to his use, and when he cannot subdue, he destroys them' (quoted in Muiu 2002: 32-33). Given the situation, the colonial state could not but be authoritarian. As Ake rightly points out:

Since the colonial state was called upon by the peculiar circumstances of the colonial situation to carry out so many functions - indeed to do 
everything - it was all powerful. It needed to be all power not only to carry out its mission but also to survive along with the colonial order in the face of the resentment and the hostility of the colonised... The power of the colonial state was not only absolute but also arbitrary (1996: 2).

And so the structures of the colonial state - security forces, public administration, churches, etc. - were designed to be authoritarian since they were apparatuses of oppression and control rather than democratic governance and development. These are the structures that were inherited by the post-colonial state in most cases close to half a century ago, and have remained essentially unchanged. Is it any wonder then, that authoritarianism is pervasive in Africa? That the African state is a predatory rather than a developmental state? (Edigheji 2004).

\section{Colonialism and Corruption}

Although corruption is now a universal phenomenon that has reached cancerous proportions, it does not seem to have existed in pre-colonial Africa. It needs no further evidence besides Ibn Battuta's observation quoted above to show that corruption is a colonial legacy that did not exist in pre-colonial Africa. It should also be noted that corruption is not an object but a societal phenomenon that necessarily entails human action. Since there is no African language word for it, it did not exist in pre-colonial Africa. As shown below, corruption is indisputably a colonial legacy.

Despite the universality of corruption there is no single commonly accepted definition of it. Moreover societies differ in their views about what constitutes corruption and scholars too disagree about its causes and effects. Normatively defined, corruption refers to the abuse or misuse of public power/position/office/role of trust or resources for private benefit (Girling 1997; Alatas 1990; Thompson 1993; Rose-Ackerman 1999; Mulinge and Lesetedi 2002). However, corruption is viewed here from the perspective of Osoba as:

a form of antisocial behaviour by an individual or social group which confers unjust or fraudulent benefits on its perpetrators, is inconsistent with the established legal norms and prevailing moral ethos of the land and is likely to subvert or diminish the capacity of the legitimate authorities to provide fully for the material and spiritual well-being of all members of a society in a just and equitable manner (1996: 372).

The origin of corruption is traced to the industrial revolution of the nineteenth century (Robb 1992). It was part of the white collar crime 
produced by the financial growth that accompanied the industrial revolution. According to Robb (1992), the industrial revolution gave rise to a complex economy characterised by an increasing dependence on finance and investment and, consequently, enormous banking networks, stocks and credit, and a complicated legal system. These factors, coupled with the increase in lawyers, financiers and other professionals, greatly aided the expansion and the potential for white collar crime. Viewed as a by-product of traits of antisocial behaviour, corruption was later introduced into Africa by the British, French and other colonial rulers (Osoba 1996). Such behaviour infiltrated indigenous African peoples during the colonial period and was nurtured in the post-colonial era. The credibility of this position is further heightened by the fact that the colonisation of Africa was an extension of the new economic order that resulted from the industrial revolution and its concomitant problems (Mulinge and Lesetedi 2002), the quest for economic gain, or 'free trade imperialism' (Nabudere 1981: 7) that accompanied the industrial revolution fuelled the scramble for, and the eventual partition and colonisation of, Africa by Europeans.

Colonialism introduced corruption to Africa in essentially three ways, namely the introduction of a monetary economy, cash taxation and the use of the divide and rule method. First, corruption requires a welldeveloped monetary economy characterised by a clear differentiation of interest to survive. Such an economic system did not exist in precolonial Africa (Mulinge and Lesetedi 2002). Thus the introduction of a monetary economy by the colonial government 'laid down the structural groundwork for the origins and sustenance of corrupt practices' (Mulinge and Lesetedi 2002: 54). The introduction of compulsory cash taxation in the forms of hut tax and, later, poll tax constituted a second avenue of corruption only because of the manner in which the tax was collected. The colonial rulers relied on local African leaders to collect the taxes. And as a motivation the latter were allowed to pocket a part of the money collected, 'a practice that amounted to the taking of kickbacks by African chiefs' (Mulinge and Lesetedi 2002: 55) and became a principal method for the accumulation of private property (Leonard 1991), a way of life that became difficult to give up just as corruption has become. Thus Tlou and Campbell rightly conclude that the financial gains accruing from the amount pocketed from 'taxes blinded the chiefs to the plight suffered by their people as a consequence of taxation' (1984). 
The technique of divide and rule adopted by colonial authorities to subdue and control Africans constituted a third link between corruption and colonialism. The technique of divide and rule involved the practice of favouring one tribe over others with a dual objective of securing the loyalty of that group to the administration and encouraging rivalry among the others to prevent a sense of unity from growing and threatening colonial rule. The favoured groups were rewarded with access to Western education (Kalinga 1985) and government-sponsored economic opportunities (Mulinge and Lesetedi 2002). This resulted in high regional variations in levels of educational attainment and economic opportunities such that at independence those favoured had an edge over those not favoured and constituted the beginnings of an African elite class that was to dominate the political and economic life of the post-colonial African countries. Unfortunately, the socialisation of this elite class into a culture that excluded the majority in favour of only a select few had sown the seeds of corrupt practices such as tribalism and nepotism that have become deeply rooted in Africa. Evidently then, corruption is, like authoritarian rule, a colonial legacy.

\section{Colonialism and Political Instability}

The link between political instability and colonialism is derived partly from the nature of the territorial boundaries of the colonial state and partly from the role of the colonisers in fostering ethnicity. In partitioning Africa among themselves, the European colonisers did not take local realities into consideration and as such, the colonial territorial boundaries were arbitrarily drawn. Thus, erstwhile autonomous groups were forcefully brought under one political administration thereby obstructing the pre-colonial process of integration and assimilation but doing nothing to assimilate the various groups into a culture of unity. As such the groups maintained and eventually carried their group identities into the post-colonial era. This is why the "majority of Africans still define themselves as citizens of their own social groups or nations' (LumumbaKasongo 2002: 91). Moreover the territorial boundaries were not accepted by the colonialists as fixed, hence most of them were redrawn several times in accordance with the changing configurations of European politics. Thus as late as the 1950s issues related to colonial boundaries were still being raised by European authorities (Lumumba-Kasongo 2002: 89). This led to some African groupings within two or more countries experiencing two or more colonial administrations. After 
independence, these boundary issues have resulted in more than ninety disputes with more than seventy-five of them leading to either shortterm or long-term wars or war-like situations. Examples include Liberia and Sierra Leone, Burkina Faso and Mali, Cameroon and Nigeria, Togo and Ghana, Eritrea and Ethiopia.

Secondly, the colonial state fostered ethnicity by encouraging ethnic sentiments among the Africans. In order to discourage a feeling of unity among the Africans the colonialists seized every opportunity to spread the myth that Africans were different from one another and used several techniques to keep them apart. They adopted a strategy of exclusion by (i) classifying ethnic groups and insisting that official forms carry information about the ethnic origin of individuals, (ii) disaggregating ethnic groups into the various subgroups, (iii) favouring some groups over others, and, (iv) in some cases separating already assimilated groups (Nnoli 1998: 16-17).This strategy of fragmentation and exclusion induced ethnic consciousness which laid the foundation of the inter-ethnic conflicts that characterise post-colonial Africa. The urge to serve ethnic interests is manifest in the tendency towards the perpetuation of power, the nepotistic allocation of national resources, the repression of ethnic groups and even the resort to genocidal massacres as have been witnessed in Liberia, Rwanda, Burundi, Sudan, and Nigeria. Hence ethnic-based military-led political instability is 'a major cause of the current African crisis' (McGowan 2003: 339). The colonial state's arbitrary boundaries which included erstwhile autonomous groups that remained unassimilated facilitated the colonialists' strategy of fragmentation that gave rise to ethnic consciousness. By inheriting the colonial structures intact, the post-colonial state also inherited the inherent instability. Thus, instability like authoritarian rule and corruption has a colonial origin. These legacies though pervasive in Africa and often presented as the obstacles to development are not indigenous to the continent. In the section that follows I will argue that these colonial legacies are sustained and reinforced by foreign aid to ensure the continuity of colonial policy.

\section{Foreign Aid and Colonial Legacies}

The conventional aid theory asserts that the insertion of external resources into the recipient economy can help to accelerate the development process by relieving specific bottlenecks caused by limited domestic resources and limited access to external resources through non-aid 
mechanisms (Chenery and Strout 1966). In other words, the purpose of foreign aid is to promote development in the recipient country. But in the development literature, aid is under attack by both rightist and leftist writers for not only failing to promote development in the recipient countries but also for actually impeding it. Those on the right argue that aid is preventing development because it inhibits the penetration and expansion of market forces in the recipient countries (Bauer 1979, 1984; Krauss 1983; Friedman 1970), while the leftists contend that aid acts as a catalyst for capitalist forces which exploit and retard rather than develop the recipient countries (Seers and Myrdal 1982; Mende 1973: Hayter and Watson 1985, Jalée 1968).

Thus, albeit for different reasons, scholars of different ideological persuasions reach the inescapable conclusion that aid impedes rather than promotes development in the recipient countries. The theoretical basis of aid is thus at variance with the empirical evidence of the effects of aid. Why then is aid still being given?. The reason is that although presented as the explanation for aid, the theory is not the basis on which aid is given. Aid is not meant for the development of the recipient countries. For one thing the theory followed rather than preceded the practice of giving aid. 'The truth', says Higgins, 'is that aid programs developed on an ad hoc basis and the effort to provide a logically consistent rationale came afterwards' (1968: 575). Moreover, the origin of aid has been traced back to the colonial links between Western imperial powers and their overseas territories (Zeylstra 1975). These links were formalised at the dawn of 'independence' by so-called cooperation agreements that validated Western pre-eminence in economic, political, cultural and military affairs and reinforced the Western mindset of the African establishments.

These colonial links that aid was meant to sustain were not, and could not be, in the interest of the colonies. Thus to those who sought to blur the truth with notions of the 'white man's burden' and 'mission civilatrice', the French Colonial Secretary Albert Sarraut quipped 'what is the use painting the truth?', and then, went on to assert that:

At the start colonisation was not an act of civilisation nor was it a desire to civilise. It was an act of force motivated by interest - the people who set out to seize colonies in distant lands were thinking primarily of themselves, and were working for their own profits and conquering for their own power ... the origin of colonisation is nothing else than enterprise of individual interest, a one-sided and egoistical imposition of the strong upon the weak (quoted in Nkrumah 1963: 21). 
The real, though often unstated, purpose of foreign aid is therefore like that of colonialism to serve the interests of the colonisers subsumed under capitalism. Foreign aid does this essentially by sustaining the colonial structures embodied in and symbolised by the post-colonial state.

Although here as in the case of colonialism the tendency is often to cloak this real purpose of aid in a smokescreen of moral obligation or 'human good', it is nevertheless quite evident. President J.F. Kennedy, for instance, was unambiguous that aid was 'a method by which the United States maintains a position of influence and control around the world and sustains a good many countries which would definitely collapse or pass into the communist bloc' (quoted in Hayter 1981: 83). This was then elucidated by L.D. Black thus:

The basic long-range goal of foreign aid is political. It is not economic development per se. The primary purpose of foreign aid is to supplement and complement the efforts of the developing nations to enhance their strength and stability and to defend their freedom. Success in these efforts is necessary to counter the spread of communism (1968: 18).

Similarly president Richard Nixon told his compatriots: 'let us remember that the main purpose of American aid is not to help other nations but to help ourselves' (Quoted in Riddell 1987: 63). Hence, the UnderSecretary for Economic Affairs had to stress that 'aid is not allocated on the basis of the needs of the recipients' (quoted in Riddell 1987: 63). This understanding of the purpose of aid is not limited to the United States. For example, Baroness Young, a Minister of State at the Foreign and Commonwealth Office, also stressed that in its broadest sense, aid must be seen in the context of our overall foreign policy objectives' (quoted in Riddell 1987: 64).

From the preceding it is obvious that the purpose of aid is to serve the capitalist interests of the so-called donors by sustaining colonial legacies, especially the authoritative and arbitrary structures of the postcolonial state in the name of 'defending freedom'. In this respect military aid is indispensable in protecting the capitalist-oriented state. Thus under the pretext of ensuring the security of the state, incumbents in Africa use the armed forces to intimidate, suppress and even eliminate actual and potential rivals.

Those African leaders like Patrice Lumumba, Kwame Nkrumah and Samora Machel, among others, who express, or are suspected of harbouring, anti-capitalist ideas, are ruthlessly eliminated. The so-called economic aid including loans plays the role of bribes to African leaders 
to help make it worth their while to continue to co-operate by accepting the status quo, with the drain of capital from their countries. This reasoning is adduced from the actions of donor governments and international organisations in continuing to give loans to countries where it is obvious that aid money is diverted to private bank accounts abroad, as well as to those which by asking for debt cancellation, declare themselves not to be credit-worthy. As a result foreign aid is a 'racket which benefits Third World politicians, the staffs of aid agencies and Western exporters at the expense of Western tax payers and ordinary people in the Third World' (quoted in Bauer 1981: 149).

The process of aid negotiation even within multilateral institutions is on an individual country basis. This requirement of negotiating on a country by country basis is like the colonial policy of divide and rule intended to emphasise the differences rather than similarities among African countries, thereby keeping them perpetually divided, weak and dependent. In this way, aid is sustaining the colonial policy of divide and rule. Furthermore, tied aid approximates corruption especially where the goods or services offered are inferior to those obtainable from elsewhere at the same price. Technical assistance constitutes a hindrance to the human resource development of the recipient country as it deprives its people of the learning experience by which required capacities could be developed and appropriate options chosen for development. This explains why 'the erosion of the African national capacity for development coincided with increase of outside assistance' (Yansané 1996).

But the greatest effect of aid is the re-colonisation of Africa that it has necessitated. Because of aid conditionalities African states have lost their marginal autonomy and are now being governed by aid officials, especially from the World Bank and the IMF. It is now common to see these aid officials 'having to approve national budgets, being posted to Central Banks and Ministries of Finance, and also, not only have to approve macro-economic policies but in some instances have to draw up such policies for African countries without input from African governments' (Edigheji 2004: 95). The global project with its requirement of good governance that entails the promotion of the various freedoms, the independence of the judiciary and the press, the conduct of democratic elections, etc., amount to the making of major political decisions for Africa by outsiders. Foreign aid is thus an avenue for the reinforcement of the political servitude and the economic subjection of Africa that was established during the colonial days. 


\section{The Way Forward}

Africa's development predicament was born of colonial rule, a rule which killed the Africans' sense of self-worth. With the establishment of colonial rule, as Frantz Fanon notes, 'history for the African comes to an end. No longer do significant events occur. Development stops' (quoted in Markovitz 1997: 10). The symbolic withdrawal of overt colonial rule did not and could not restore the Africans' sense of self-worth and reverse the situation because measures were put in place to ensure continuity. These measures - authoritarian rule, corruption and ethnicity (colonial legacies) are embodied in and symbolised by the post-colonial state which is sustained and reinforced by foreign aid to keep Africa divided and weak for exploitation. The consequence is that Africa has become a beggarly neighbour and Africans the scum of the earth. The one thing which is certain is that Africa will continue to be at the bottom of the world economic heap unless something is done, unless action is taken to change the status quo, by recapturing and appropriating the African state.

In order to change the status quo and get Africa out of its predicament I propose a three-stage way forward involving the repudiation of foreign aid and the restructuring of the post-colonial state's territorial boundaries as preparatory steps for the establishment of an African continental government. Besides its role in sustaining and reinforcing the colonial legacies mentioned above, foreign aid also obstructs development in Africa. First, it does so through capital flight mainly in the form of debt servicing, and secondly, by facilitating acceptance by African leaders of (a) Western economic decisions on pricing and restrictions in international trade which adversely affect African products and the balance of trade; and (b) political decisions on the nature of governance that facilitate capitalist penetration and exploitation of their economies. Foreign aid is thus part of the problem and cannot therefore be expected to provide a solution. Aid should be rejected not only because it cannot help but more importantly because it actually hurts. It is neither the type nor even the amount of routine official foreign aid that is the issue because in all forms and quantities it is inimical to African development.

Therefore, the appropriate starting point for the way forward for Africa is the rejection of foreign aid. This entails the utter repudiation of all forms of foreign aid, except perhaps, disaster relief assistance, along with the unilateral abrogation of all foreign debts. The unilateral 
nature of these acts is intended to differentiate them from the so-called Highly Indebted Poor Countries Initiative, which is merely a device for the consolidation of the status quo and the perpetuation of Africa's political servitude and economic subjection. This is a precondition for charting a way forward for Africa. Because aid is the main avenue for foreign intervention in and control of Africa, the repudiation of it is tantamount to, other things being equal, the prevention of that intervention. Africans will then be able with a free hand to restructure their societies in accordance with their realities.

The repudiation of aid and the abrogation of foreign debts is by no means an end in itself. It is only the necessary first step in a three-prong way forward for Africa. One of Africa's thorniest problems is political instability which is caused by ethnicity and manifest in inter-ethnic and interstate conflicts, civil wars, military coups and the tendency towards ethnic domination and the perpetuation of power. Ethnicity is, as shown in section one above, a colonial legacy arising from the artificial and arbitrary boundaries of the colonial state which were drawn to reflect foreign rather than African interests and which were inherited intact by the post-colonial state. Thus, ethnicity which is the main, if not the sole cause of political instability in post-colonial Africa is largely a function of the nature of the post-colonial state's boundaries.

Therefore, the second necessary step in the way forward for Africa after the elimination of foreign aid is the restructuring of territorial boundaries with a view to eliminating or, at least, greatly reducing political instability. As much as possible the restructuring should respect ethnic divisions so as to avoid what the Rudolphs call the "pathology of national integration' that is, the pursuit of unity without regard for ascriptive local identities, as well as the emergence of the "pathology of diversity', that is, a nation state with too limited a sense of citizenship (quoted in Markovitz 1977: 109). This proposal for the restructuring of boundaries in Africa to reflect ethnic divisions is justified on several grounds. Firstly, in spite of, or even because of, the pathology of national integration, Africans, as mentioned above, still define themselves as citizens of their own ethnic groups or nations. This is evidenced by the ethnicisation of politics in Africa, as Nyamnjoh and Rowlands (1998: 334) show in the case of Cameroon, and this applies to other African countries as well, ethnic considerations or what they call the "politics of belonging' act to 'subvert urban civil society into familiar forms of ethnically defined patrimonialism', or what Geschiere and Gugler term 
'villagisation of national politics' (1998: 319). As such, party cleavages in Africa are 'overwhelmingly ethno-linguistic in nature' (Van de Walle 2002: 321 ).

Secondly, as Lumumba-Kasongo points out, many ethnic nationalities in Africa favour the 'reconsideration of frontiers/ boundaries as a means of redefining their cultural identities and politics', as shown by the pan-Ewe movement in Togo and Ghana, the Bakongo movement in the Democratic Republic of Congo, Congo Brazzaville and Angola, and the desire of the Akan groups in southern Côte d'Ivoire to join other Akans in Ghana (2002: 92). Thirdly, in many countries in Africa ethnicity has reached a point of no return or what Nnoli (1994: 31-32) terms a 'threshold of irreversibility' by erupting into bloody conflicts in the form of civil wars as has happened in Nigeria, Burundi, Rwanda, Liberia, Sierra Leone, Somalia, Ethiopia, Democratic Republic of Congo, Côte d'Ivoire, etc. Ethnic animosities are exacerbated and internalised by such conflicts to remain permanent obstacles to the development of a sense of national unity as well as democratic governance. Such animosities 'are passed on to successive generations through the family, the press, public and private conversations, such that even when the original basis of ethnic hostility has been eliminated ... there remains the problem posed by this internalised dimension which may continue to impact on other variables such as multiparty democracy' (Nnoli Ibid).

The fourth and final factor is closely related to the third. It is the fact that ethnically homogenous groups are found to be more conducive than heterogeneous ones to the development of democratic values and practices (MacLean 2004). This is essentially as a result of the mutual trust that exists among the members of the former group. Consequently, it is arguable that ethnically homogenous African states could be more conducive than heterogeneous ones for the formation of a continental government. In the present set up ethnic interest necessitates the acquisition of power by all means, its perpetuation and arbitrary exercise, that is, there is no agreement on how power is acquired, its duration and manner of exercise, and as such, there can be no agreement about relinquishing part of that power to a continental government. On the other hand, it seems easier for the leadership of an ethnically homogenous state to agree to relinquish some of its powers to a continental government because of the certainty of its interest being represented at that level by some of its kin than it is for the leadership of an ethnically heterogeneous state because of the fear of one's group 
losing out arising from the uncertainty of representation. The fact, as mentioned above, that power is acquired at the national level either by force or fraud rather than by impersonal procedures reinforces this fear. Moreover the role of ethnic homogeneity in providing a conducive atmosphere for development is demonstrated by the fact that each of the often quoted success stories - Taiwan, South Korea, and Hong Kong is culturally homogenous.

The post-colonial state which was designed to serve foreign interests must be recaptured and restructured to serve African interests. It is certain that those who benefit from the status quo, that is, the metropolitan elite and their African compradores, will guilefully argue that restructuring territorial boundaries will further balkanise and weaken Africa. The status quo has rendered Africa the poorest region in the world; it is not just prostrate, but is actually lying flat on its back. And so the question is, whose interest is the status quo serving? And, can Africa be any weaker than it currently is? To assume that Africa can be weaker is implying that one can die beyond death. Moreover, and besides the fact that the restructuring is only a stepping stone, there is no reason to suppose that the restructuring will necessarily produce states that are smaller than the present ones. For instance, a state composed of the Fangs in Cameroon, Gabon, and Equatorial Guinea would be much larger than either of the last two named states. The same could be true of other groups in Africa.

As we have seen, ethnicity arising from arbitrary territorial boundaries is the source of political instability in Africa. Therefore, restructuring the state in accordance with ethnic realities is a must if Africa has to be liberated. Nnoli (1998: 25) similarly agrees that since the state is "central to the dynamics of ethnicity in Africa, ethnic conflict prevention and termination must address the issue of its reconstitution and transformation'. There is thus everything to gain and nothing to lose save the status quo with its implied misery for Africa, by restructuring territorial boundaries.

The final stage in the way forward for Africa is the establishment of a continental government which can only be feasible if preceded by the elimination of foreign aid and the restructuring of territorial boundaries.

The need of a continental government for Africa was recognised and emphasised by Kwane Nkrumah several decades ago: 
... the continental union of Africa is an inescapable desideratum if we are determined to move forward to a realisation of our hopes and plans for creating a modern society which will give our peoples the opportunity to enjoy a full and satisfying life (1963: 224).

But Nkrumah was also aware of the fact that the efforts of Africans towards the formation of a continental government were being frustrated by neo-colonialists by 'encouraging the formation of communities based on the languages of their former colonisers' (217). The formation of regional communities is essentially a continuation of the colonial policy of divide and rule intended to serve foreign interest. This is evidenced by the absence of interregional trade among the regions and by the fact that both intra- and inter-regional communications are much more difficult than communication between any of the regions and the West. As Ninsin (2000: 15) also pointedly argues, 'colonial political, economic and ideological ties compounded by calculated manipulation of such ties by the former colonial powers account partly for the failure of the numerous integration projects on the continent'.

These colonial ties have been sustained by foreign aid to ensure the continuity of colonial policy in the form of neo-colonialism which has now metamorphosed into re-colonialism. Therefore, the need for a continental government is more compelling than ever before. The political, military, economic and socio-cultural advantages of a continental government are inestimable and cannot be over-emphasised.

The continental government envisaged here is necessarily a bicameral federation or union in which the member states have to be sufficiently autonomous to control their citizens and manage their internal affairs without foreign interference. At the central level, the interests of the states would be represented in the upper house of the bicameral legislature whose composition and functioning would be based on the principle of sovereign equality of states, while the citizens of the various states would be represented in the lower house. Moreover, in terms of power sharing, the central government and the member states would exercise concurrent powers in all but the areas of defence, currency and foreign affairs, which though reserved to the central government, would still be under the control and scrutiny of the member states through their representatives in both houses of the central legislature. This is the only way by which the African state can regain its sovereignty, and the African, his sense of self-worth. 
The continental market that would result from the union would be facilitated by a common currency to provide enormous economic opportunities. Similarly, while being better placed to ensure continental security, a unified military command would release, for developmental purposes, the enormous financial resources now being used to sustain the armed forces of the various states. The serenity resulting from the elimination of ethnic conflicts through the restructuring of territorial boundaries would offer a conducive atmosphere for concerted efforts in planning and implementing development projects. The current African Union is an international organisation, not a government, and should not therefore be confused with the continental government being proposed here. Moreover, its desire for foreign aid as evidenced by its NEPAD strategy and its insistence (Article 4(c) of its Constitutive Act) on 'the respect of borders existing on achievement of independence' are indicative of its purpose. It is antithetical to the way forward for Africa and would at the appropriate moment be dismantled along with other colonial legacies to be replaced with the type of continental government envisaged here.

Decisions on foreign policy, defence and currency are the hallmarks of sovereignty, yet since colonial days these have been made for Africans by foreigners. This has been because the balkanisation and colonisation of Africa resulted in dependent, inappropriately composed and conflictridden states that have been unable individually to ward off foreign domination. The only way of recapturing and appropriating Africa and ensuring that African interest is served is within a continental framework whose design, objectives and functioning are informed by African circumstances and needs. This is a new struggle which though similar to the nationalist struggle against overt colonial rule, will nevertheless be different in being protracted for two reasons. First, the current domination has internal collaborators in the African political and economic elites whose overall objective is to ensure their survival by maintaining the status quo, and secondly, the political, economic and cultural forces of the current domination are too subtle to be perceived by the man on the street. This implies that the status quo will remain for the foreseeable future. Yet we must begin to chart a way forward as outlined above, if Africa is to be recaptured and made to serve African interests.

For this purpose, the rule of the African academia would be indispensable. Because of their knowledge about the disastrous effects of foreign domination, the African academia must be in the vanguard of 
African liberation. They must take the responsibility to educate the masses: about the disastrous effects of foreign domination through foreign aid; the necessity for restructuring the post-colonial state; and the political, economic, military, social, cultural and psychological benefits to be derived from a continental government. These should constitute a straightforward and easy to understand package for the intensive and extensive education of the masses, and in fact, of everybody across the continent. As Murungi (2003: 20) rightly points out, 'what Africa needs is a revolutionary education, an education whose mission is to liberate Africa humanity'. African intellectuals should not shirk the responsibility which because of their status, nature has assigned them. And remember that a job once started is half done, and that, the journey of a thousand miles starts with the first step.

\section{Reierences}

African Union, 2000, Constitutive Act of the African Union, Lome,Togo.

Ake, C., 1996, Democracy and Development in Africa, Washington DC: The Brookings Institute.

Alatas, S. H., 1990, Corruption: Its Nature, Causes and Functions, Aldershot: Avebury. Amin, S., 1990a, Maldevelopment, London: ZED/UBU.

Amin, S., 1990b Delinking: Towards a Polycentric World, London: ZED Books.

Bauer, P. T., 1979, 'Foreign Aid Viewed Differently', Aussenwirtschaft, September, pp. 35-54.,

Bauer, P. T., 1981, Equality, the Third World and Economic Delusion London: Weidenfeld and Nicolson.

Bauer, P. T., 1984, Reality and Rhetoric London: Weidenfeld and Nicolson.

Black, L. D., 1968, The Strategy of Foreign Aid, Toronto: Van Nostrand.

Busia, K. A., 1962, The Challenge of Africa, New York: Praeger.

Chenery, H. and Strout, A. M., 1966, 'Foreign Assistance and Economic Development', The American Economic Review, vol. LVI, September, pp. 10-25.

Edigheji, O., 2004, 'The African State and Social-Economic Development: An Institutional Approach', African Journal of Political Science, vol. 9, no. 1, pp. 84-103.

Fanon, F., 1968, The Wretched of the Earth, New York: Grove Press.

Friedman, M., 1970, 'Foreign Economic Aid: Means and Objectives', in J., Bhagwati and R. S. Eckaus, eds., Foreign Aid, London: Penguin, pp. 64-88.

Geschiere, P. and Gugler, J., 1998, 'The Urban-Rural Connection: Changing Issues of Belonging and Identification', Africa, vol. 68, no. 3, pp. 453-471.

Girling, J., 1997, Corruption, Capitalism and Democracy, London: Routledge.

Goulet, Denis, 1971 , The Cruel Choice: A New Concept in the Theory of Development New York.Atheneum

Hayter, T. and Watson, C., 1985, Aid: Rhetoric and Reality, London: Pluto.

Higgins, B., 1968, Economic Development, London: Constable.

Jalée, P., 1968, The Pillage of the Third World, New York: Monthly Review Press. 
Joseph, R. A., 2003, 'Facing Africa's Predicament: Academe Needs to Play a Stronger Role', Chronicle of Higher Education, March, pp. 30-51.

Kalinga, O. J. M., 1985, 'Colonial Rule, Missionaries and Ethnicity in the North Nyasa District, 1891-1938', African Studies Review, vol. 28, no. 1, pp. 57-72.

Krauss, M., 1983, Development Without Aid, New York: McGraw Hill.

Leonard, D. K., 1991, African Successes: Four Public Managers of Kenyan Rural Development, Los Angeles: University of California Press.

Linton, R., 1959, The Tree of Culture, New York: Vintage Books.

Lumumba-Kasongo, T., 2002, 'Reconceptualizing the State as the Leading Agent of Development in the Context of Globalisation in Africa', African Journal of Political Science, vol. 7, no 1, pp. 79-108.

MacLean, L. M., 2004, 'Mediating Ethnic Conflict at the Grassroots: The Role of Local Associational Life in Shaping Political Values in Côte d'Ivoire and Ghana', Journal of Modern African Studies, vol. 42, no 4, pp. 589-617.

Markovitz, I. L., 1997, Power and Class in Africa, Englewood Cliffs, NJ: PrenticeHall.

McGowan, P. J., 2003, 'African Military Coups d'Etat 1956-2001: Frequency, Trends and distribution', Journal of Modern African Studies, vol. 41, no 3, pp. 339-370.

Mende, T., 1973, From Aid to Recolonisation: Lessons of a Failure, London: Harrap.

Mkandawire, T. and Soludo, Charles C. 1999, Our Continent, Our Future: African Perspectives on Structural Adjustment, Dakar: CODESRIA.

Muiu, Muen Wa, 2002, 'Fundi Wa Afrika; Toward a New Paradigm of the African State', Journal of Third World Studies, vol. xix, no. 2, pp. 23-43.

Mulinge, M. M. and Lesetedi, G. N. 2002, 'Corruption in Sub-Saharan Africa: Towards a More Holistic Approach', African Journal of Political Science, vol. 7, no. 1, pp. 51-77.

Murungi, J., 2003, 'The Academy and the Crisis of African Governance', African Issues vol. 3 no. 1 pp. 9-23.

Nabudere, D., 1981, Imperialism in East Africa; Imperialism and Exploitation, London: Zed Books.

Ninsin, K. A., 2000, 'Globalisation and the Future', AAPS Occasional Paper Series, vol. 4, no. 1, pp. 3-33.

Nkrumah, K., 1963, Africa Must Unite, London: Panaf Books.

Nnoli, O., ed., 1998, Ethnic Conflict in Africa, Dakar: CODESRIA Books.

Nyamnjoh, F. and Rowlands, M., 1998, 'Elite Associations and the Politics of Belonging in Cameroon’, Africa, vol. 68, no. 3, pp. 320-337.

Osabu-Kle, D. T., 2000, Compatible Democracy: The Key to Development in Africa, Peterborough, Ontario: Broad View Press.

Osoba, S. O., 1996, 'Corruption in Nigeria: Historical Perspectives', Review of African Political Economy, vol. 69, no 1, pp. 371-386.

Riddell, R. C., 1987, Foreign Aid Reconsidered, Oxford: James Currey.

Robb, G., 1992, White Collar Crime in Modern England, London: Cambridge University Press.

Rose-Ackerman, S., 1999, Corruption and Government: Causes Consequences and Reform, Cambridge: Cambridge University Press. 
Seers, D. and Myrdal, G., 1982, 'The Withering of Aid', The Guardian 28 May. Thompson, D. F., 1993, 'Mediated Corruption: The Case of the Keating Five', American Political Science Review, vol. 87 no. 2, pp. 369-381.

Tlou, T. and Campbell, A., 1984, History of Botswana, Gaborone: Macmillan Botswana Publishing Company.

Van de Walle, N., 2002, 'Presidentialism and Clientelism in Africa's Emerging Party Systems', Journal of Modern African Studies vol. 41 no 2 pp. 305-328.

World Bank, 1994, Adjustment in Africa: Reforms, Results and the Road Ahead, Oxford: Oxford University Press.

Yansané, Ag. Y., ed., 1996, Prospects for Recovery and Sustainable Development in Africa, London: Greenwood Press.

Zeylstra, W. G., 1975, Aid or Development: The Relevance of Development Aid to Problems of Developing Countries, Leiden: A.W. Sijth. 
